\title{
PENINGKATAN HASIL BELAJAR SISWA \\ TENTANG PEMBELAJARAN SOAL CERITA OPERASI HITUNG CAMPURAN MELALUI MODEL KOOPERATIF TIPE STAD DI KELAS III SDN 44 PAREPARE
}

\author{
Yonathan Saba' Pasinggi \\ UPP PGSD Parepare Fakultas Ilmu Pendidikan UNM \\ yonathan.s.pasinggi@unm.ac.id
}

\begin{abstract}
ABSTRAK
Penelitian ini bertujuan untuk mengetahui bagaimanakah proses penerapan model kooperatif tipe STAD dalam meningkatkan pemahaman siswa soal cerita operasi hitung campuran di kelas III, serta untuk meningkatkan hasil belajar siswa soal cerita operasi hitung campuran di kelas III melalui penerapan model kooperatif tipe STAD. Pendekatan yang digunakan dalam penelitian yaitu kualitatif jenisnya PTK Hasil penelitian menunjukkan peningkatan yang signifikan dengan hasil evaluasi pada masing-masing siklus sebagai berikut. Siklus I berada pada kualifikasi cukup (C), penelitian dilanjutkan pada siklus ke II hasilnya baru berada pada kategori B sehingga melanjutkan ke siklus III dan hasilnya berada pada kategori sangat baik (SB), sehingga penelitian dihentikan.
\end{abstract}

\section{Kata Kunci: Hasil Belajar, Operasi Hitung Campuran, Model Kooperatif Tipe STAD}

\section{PENDAHULUAN}

Tujuan Mata pelajaran Matematika SD dalam Kurikulum Tingkat Satuan Pendidikan (KTSP) 2006 yaitu untuk membekali peserta didik dengan kemampuan berpikir logis, analisis, sistematis, kritis dan kreatif serta kemampuan bekerjasama. Kompetensi tersebut diperlukan agar peserta didik memiliki kemampuan memperoleh, mengelola, dan memanfaatkan informasi untuk bertahan hidup pada keadaan yang selalu berubah, tidak pasti dan kompetitif.

Salahsatu materi dalam mata pelajaran Matematika yang harus dikuasai oleh siswa sekolah dasar adalah soal cerita operasi hitung campuran. Pemecahan masalah matematika merupakan bagian yang sangat penting dari kurikulum Matematika karena dalam proses pembelajaran maupun penyelesaiannya, siswa dimungkinkan memperoleh pengalaman menggunakan pengetahuan yang sudah dimiliki dan diterapkan dalam kehidupan mereka sehari- hari.

Penyelesaian soal cerita diajarkan disetiap jenjang tingkat kelas. Hal ini menunjukkan bahwa penyelesaian soal cerita merupakan salah satu materi pelajaran yang dianggap penting. Menurut Hamdani (2009) dalam pembelajaran soal cerita, seorang siswa yang mampu menguasai aspek ingatan, serta aspek pemahaman, maka ia akan mampu menguasai aspek penerapan. Namun, mengapa sebagian besar siswa menganggap sulit soal cerita matematika?.

Pembelajaran Matematika, siswa kelas III SD, diharapkan mampu menyelesaikan soal operasi hitung campuran. Namun pada kenyataannya siswa kurang mampu menyelesaikan soal jika diberikan dalam bentuk soal cerita. Fakta rendahnya kemampuan siswa dalam menyelesaikan soal cerita operasi hitung campuran, terjadi pada siswa kelas III SDN 44 Parepare.

Dari hasil wawancara dengan siswa terungkap bahwa, siswa kurang mampu menyelesaikan soal cerita operasi hitung campuran, siswa kurang memahami langkahlangkah dalam penyelesaian soal cerita operasi hitung campuran.

Setelah diidentifikasi secara kolaboratif antara peneliti dan guru terungkap bahwa, dari aspek siswa disebabkan karena siswa kurang mampu menganalisis soal cerita dengan baik, kurang memahami tentang tahapan dalam penyelesaian soal cerita, serta kurang mencermati satuan-satuan yang diketahui dan yang ditanyakan pada soal cerita operasi hitung campuran. Selain itu dalam proses pembelajaran siswa kurang berinteraksi dengan siswa yang lain untuk bekerja bersamasama menyelesaikan soal cerita operasi hitung campuran. 
Sementara dari aspek guru disebabkan karena guru kurang memberikan petunjuk tentang cara-cara pengerjaan soal cerita operasi hitung campuran, guru tidak menggunakan media dalam mengajarkan soal cerita operasi hitung campuran, selain itu pembelajaran yang dilakukan oleh guru masih bersifat tradisional, yaitu guru lebih banyak aktif daripada siswa, siswa hanya sebagai pendengar yang pasif, selain itu guru tidak melibatkan siswa dalam memanipulasi konsep dan membuktikannya. Padahal dalam KTSP (Depdiknas,2006) pembelajaran matematika, siswa dituntut dapat menggunakan penalaran pola dan sifat serta mampu memanipulasi konsep dan membuktikannya. Untuk itu guru sebagai ujung tombak merupakan penentu keberhasilan proses pembelajaran, dan melaksanakan kurikulum untuk mewujudkan pembelajaran berkualitas sesuai visi, misi dan tujuan sekolah.

Belajar dalam kelompok kooperatif dapat membantu siswa dalam menemukan konsep-konsep yang sulit karena siswa saling bekerjasama dalam menganalisis soal cerita operasi hitung campuran. Sebagaimana Slavin (Nur,2006:11) mengatakan bahwa Belajar Kooperatif adalah suatu variasi metode pembelajaran yaitu siswa belajar bersama, saling menyumbang pemikiran dan bertanggungjawab terhadap pencapaian hasil belajar secara individu maupun kelompok.

Tipe STAD ini dipandang sebagai model pembelajaran yang sesuai dalam pelajaran matematika, karena tipe STAD memiliki beberapa-beberapa kelebihan Kagan (Masniladevi,2003:8), diantaranya semua siswa memiliki kesempatan untuk menerima reward setelah menyelesaikan materi pelajaran, dan mempunyai kemungkinan untuk mencapai hasil belajar yang tinggi, serta memberikan motivasi berprestasi. Penerapan model kooperatif tipe STAD dirasakan cocok bagi siswa kelas III SD dalam menyelesaikan soal cerita operasi hitung campuran.

Pembelajaran yang bernaung dalam teori Kontruktivis adalah kooperatif. Model kooperatif adalah pembelajaran yang secara sadar menciptakan interaksi yang saling asah sehingga sumber belajar bagi siswa bukan hanya guru dan buku ajar, tetapi juga sesama siswa. Menurut lie (Wena,2008:189) pembelajaran kooperatif adalah sistem pembelajaran yang memberi kesempatan kepada siswa untuk bekerja sama dengan sesama siswa dalam tugas-tugas yang terstruktur, dan dalam sistem ini guru bertindak sebagai fasilitator. Berdasarkan beberapa pengertian di atas dapat disimpulkan bahwa pembelajaran kooperatif adalah sistem pembelajaran yang berusaha memanfaatkan teman sejawat (siswa lain) sebagai sumber belajar, disamping guru dan sumber belajar yang lain.

Jadi hakekat sosial dan penggunaan kelompok sejawat menjadi aspek utama dalam pembelajaran kooperatif, sehingga dapat melatih keterampilan-keterampilan kerjasama dan kolaborasi dan juga keterampilanketerampilan tanya jawab. STAD dikembangkan oleh Robert slavin dan temantemannya yang menyatakan bahwa pendekatan pembelajaran kooperatif yang paling sederhana. Guru yang menggunakan STAD juga mengacu kepada belajar kelompok siswa, menyajikan informasi akademik baru kepada siswa dalam minggu menggunakan presentasi verbal atau teks. Siswa dalam satu kelas tertentu dipecah menjadi kelompok dengan anggota 4-5 orang. Setiap kelompok haruslah heterogen, terdiri dari laki-laki dan perempuan, berasal dari berbagai suku, memiliki kemampuan tinggi, sedang, dan rendah anggota tim.

Kegiatan pembelajaran model STAD terdiri dari tujuh tahap, yaitu (1) Persiapan pembelajaran, (2) Penyajian materi, (3) Belajar kelompok, (4) Pemeriksaan hasil kegiatan kelompok, (5) Siswa mengerjakan soal-soal tes secara Individual, (6) Pemeriksaan hasil tes, dan (7) Penghargaan kelompok.

\section{METODE PENELITIAN}

Pendekatan yang digunakan dalama penelitian ini adalah pendekatan deskriptif kualitatif. Pendekatan ini digunakan bertujuan untuk mendeskripsikan aktifitas siswa dan guru dalam pelaksanaan tindakan pembelajaran. Penelitian ini adalah penelitian tindakan kelas (PTK) karakteristik yang khas dari penelitian tindakan kelas yakni tindakantindakan (aksi) yang berulang-ulang untuk memperbaiki proses belajar mengajar di kelas, Kemmis dan Taggar (dalam Wardani 2005:16) yang mengatakan bahwa proses penelitian tindakan merupakan siklus atau proses daur ulang yang terdiri dari empat diawali dari aspek mengembangkan perencanaan, kemudian melakukan tindakan sesuai dengan rencana, observasi, pengamatan terhadap tindakan, dan pembelajaran yang dapat meningkatkan pemahaman siswa tentang konsep operasi hitung campuran. 
Untuk pengumpulan data dalam penelitian ini dilakukan dengan tes, wawancara, pengamatan, dan catatan lapangan. Empat teknik tersebut diuraikan sebagai berikut :1) Tes adalah serangkaian pertanyaan atau latihan atau alat lain yang digunakan untuk mengukur keterampilan, pengetahuan, intelegensia, kemampuan atau bakat yang dimiliki oleh individu atau kelompok. 2) Observasi adalah cara mengumpulkan data dengan mengadakan pencatatan lapangan terhadap apa yang menjadi sasaran pengamatan. Observasi dilakukan untuk mengamati kesesuaian antara pelaksanaan tindakan dan perencanaan yang telah disusun dan untuk mengetahui sejauh mana pelaksanaan tindakan dapat menghasilkan perubahan yang sesuai dengan yang dikehendaki. 3) Wawancara adalah pengumpulan data/ informasi yang dilaksanakan dengan tanya jawab secara lisan. Wawancara dimaksudkan untuk menggali kesulitan siswa dalam menyelesaikan soal cerita operasi hitung campuran 4) Dokumentasi merupakan data yang diperoleh dari dokumen sekolah.

Analisis data yang digunakan dalam penelitian ini adalah analisis deskriptif kualitatif. Analisis ini dimaksudkan untuk mendeskripsikan semua gejala-gejala yang didapatkan selama penelitian berlangsung yang dilakukan dengan membandingkan data hasil tes, pengamatan, wawancara dan dokumentasi.

\section{HASIL \& PEMBAHASAN}

\section{Hasil Penelitian}

Berdasarkan dari tes awal yang diperoleh siswa dimasukkan dalam format pembentukan kelompok STAD seperti lampiran 3, diperoleh 4 kelompok yang beranggotakan 4 orang siswa. Pembentukan kelompok STAD seperti yang telah diuraikan memungkinkan siswa yang berkemampuan rendah dan sedang akan berkelompok dengan siswa yang berkemampuan tinggi. Pembentukan kelompok juga didasarkan atas jenis kelamin yang terdiri dari kelompok $1: 1$ orang laki-laki, dan 3 orang perempuan, kelompok 2: 1 laki-laki dan 3 perempuan, kelompok 3 : 1 laki-laki dan 3 perempuan, kelompok 4: 1 laki-laki dan 3 perempuan.

Rencana pembelajaran setiap tindakan telah disusun dan telah dikonsultasikan dengan dosen pembimbing. Untuk mengamati aktivitas Peneliti dan siswa selama proses pembelajaran.Pada akhir pembelajaran guru bersama-sama siswa menyimpulkan materi pembelajaran dan menutup pelajaran.

Dari hasil tindakan perbaikan pembelajaran soal cerita operasi hitung campuran dengan menerapkan model kooperatif tipe STAD. Maka, siswa yang memperoleh hasil tes formatif menunjukan pada tahap tes awal nilai rata-rata dengan presentase ketuntasan 18,75 \%, setelah diadakan tindakan pada siklus I, nilai siswa mengalami peningkatan yaitu nilai rata-rata dengan ketuntasan belajar 43,75\%. Yakni siswa yang memperoleh nilai 90 - 100 dengan katergori sangat baik tidak ada, sedangkan 80 - 89 dikategorikan baik juga tidak ada, serta yang memperoleh nilai $70-79$ dengan kategori sedang sebanyak 7 orang siswa dan yang mendapatkan nilai $<70$ dengan kategori rendah sebanyak 9 siswa.

Berdasarkan uraian tersebut terlihat bahwa tujuan yang ingin dicapai pada pembelajaran siklus I belum tercapai secara optimal sebab masih ada beberapa siswa yang belum bias memahami materi dengan baik. Hal ini sesuai dengan hasil tes yang didapatkan siswa pada siklus I dengan nilai rata-rata kelas adalah 60,31 dengan ketuntasan belajar 43,75\% dengan kategori sangat kurang (SK).

Pembelajaran dilanjutkan pada tindakan siklus II, direncanakan bahwa pembelajaran soal cerita operasi hitung campuran melalui model kooperatif tipe STAD terdiri dari 7 tahap pembelajaran yaitu: a). Persiapan pembelajaran, b). penyajian materi, c). kegiatan belajar kelompok, d). pemeriksaan terhadap hasil belajar kelompok, e). siswa mengerjakan tes secara individual, $\mathrm{f}$ ). pemeriksaan hasil tes, g). penghargaan kelompok.

Dari hasil tindakan perbaikan pembelajaran soal cerita operasi hitung campuran dengan menerapkan model kooperatif tipe STAD. Maka, siswa yang memperoleh hasil tes formatif menunjukan pada tindakan siklus I nilai rata-rata dengan presentase ketuntasan 43,75 \%, setelah diadakan tindakan pada siklus II, nilai siswa mengalami peningkatan yaitu nilai rata-rata dengan ketuntasan belajar 62,5\%. Yakni siswa yang memperoleh nilai $90-100$ dengan katergori sangat baik sebanyak 3 orang sedangkan 80 - 89 dikategorikan baik sebanyak 1 orang, serta yang memperoleh nilai $70-79$ dengan kategori sedang adalah 6 orang dan yang mendapatkan nilai $<70$ dengan kategori rendah sebanyak 6 orang. 
Berdasarkan uraian tersebut terlihat bahwa tujuan yang ingin dicapai pada pemebelajaran siklus II belum tercapai secara optimal, sebab masih ada siswa yang belum memahami materi dengan baik. Hal ini sesuai dengan hasil tes yang didapatkan siswa pada siklus II dengan nilai rata-rata yang diperoleh siswa adalah 68,75 dengan ketuntasan belajar $62,5 \%$ dengan kategori cukup (C).

Kegiatan pelaksanaan pada siklus II belum memenuhi stantar ketuntasan maka dilanjutkan pada siklus III, direncanakan bahwa pembelajaran soal cerita operasi hitung campuran melalui model kooperatif tipe STAD terdiri dari 7 tahap pembelajaran yaitu: a). Persiapan pembelajaran, b). penyajian materi, c). kegiatan belajar kelompok, d). pemeriksaan terhadap hasil belajar kelompok, e). siswa mengerjakan tes secara individual, $\mathrm{f}$ ). pemeriksaan hasil tes, g). penghargaan kelompok.

Dari hasil tindakan perbaikan pembelajaran soal cerita operasi hitung campuran dengan menerapkan model kooperatif tipe STAD. Maka, siswa yang memperoleh hasil tes formatif menunjukan pada tindakan siklus II nilai rata-rata dengan presentase ketuntasan $62,5 \%$, setelah diadakan tindakan pada siklus III, nilai siswa mengalami peningkatan yaitu nilai rata-rata dengan ketuntasan belajar $100 \%$. Yakni siswa yang memperoleh nilai 90 - 100 dengan katergori sangat baik sebanyak 10 orang sedangkan 80 89 dikategorikan baik sebanyak 1 orang, serta yang memperoleh nilai $70-79$ dengan kategori sedang adalah 5 orang dan yang mendapatkan nilai $<70$ dengan kategori rendah tidak ada.

Berdasarkan uraian tersebut terlihat bahwa tujuan yang ingin dicapai pada pembelajaran siklus III sudah tercapai secara optimal sebab siswa sudah memahami materi dengan baik. Hal ini sesuai dengan hasil tes yang didapatkan siswa pada siklus III dengan rata-rata nilai yang diperoleh siswa 89,35 dengan ketuntasan belajar $100 \%$ dengan kategori sangat baik (SB).

\section{PEMBAHASAN}

Pada bab ini akan dibahas mengenai pembelajaran model kooperatif tipe STAD dapat meningkatkan hasil belajar siswa pada materi soal cerita operasi hitung campuran di kelas III SDN 44 Parepare. Pembelajaran soal cerita operasi hitung campuran dengan model STAD dalam penelitian ini meliputi beberapa kegiatan, yaitu (1) persiapan materi pembelajaran, (2) penyajian materi, (3) kegiatan belajar kelompok, (4) pemeriksaan terhadap hasil belajar dalam kelompok, (5) mengerjakan soal secara individu, (6) pemeriksaan hasil tes individu, dan (7) pemberian penghargaan kelompok.

Sebelum pelaksanaan pembelajaran dengan model terlebih dahulu dilakukan pembentukan kelompok. Proses pembentukan kelompok dilakukan sebelum pemberian tindakan. Hal ini dilakukan dengan pertimbangan untuk menghemat waktu. Pembentukan anggota kelompok didasarkan pada kemampuan dengan pertimbangan jika siswa yang mempunyai kemampuan yang berbeda dimasukan dalam kelompok yang sama maka siswa yang berkemampuan sedang dan rendah akan termotivasi untuk belajar.

Pembentukan kelompok juga didasarkan atas jenis kelamin. Hal ini dilakukan karena tujuan penelitian ini juga akan melihat bagaimana motivasi siswa dalam diskusi kelompok maupun diskusi kelas. Jadi terdapat empat kelompok yang tiap-tiap kelompok terdiri dari 4-5 orang siswa.

Pembelajaran materi soal cerita operasi hitung campuran dengan model STAD dapat dijelaskan sebagai berikut:

\section{Persiapan Pembelajaran}

Menyiapkan LKS, alat peraga dan lembar observasi. Sebelum menyajikan materi pelajaran, peneliti membuat lembar kerja siswa yang dipelajari kelompok, lembar jawaban, dan lembar pengamatan kegiatan serta alat peraga yang digunakan dalam pembelajaran.

Menempatkan Siswa dalam Kelompok

Pembentukan kelompok siswa duduk berdasarkan kelompok yang telah ditetapkan sebelumnya. Jumlah anggota kelompok ditetapkan sebanyak 4-5 orang siswa dalam satu kelompok, Dengan alasan jika ukuran kelompok terlalu banyak sulit bagi setiap siswa untuk mengemukakan pendapat dan melakukan kerjasama dan jika ukuran kelompok terlalu kecil interaksi sesama anggota kelompok akan sangat terbatas.

\section{Menentukan Skor Dasar}

Skor dasar merupakan skor siswa pada tes kemampuan prasyarat/tes awal. Setelah memberikan tes kemampuan prasyarat/tes awal, maka skor tersebut dapat dijadikan sebagai skor dasar. 


\section{Penyajian Materi}

Penyajian materi soal cerita operasi hitung campuran pada pada siklus I, II dan III memakan waktu 90 menit. Peneliti dimulai dengan mengucapkan salam, menyampaikan tujuan pembelajaran yang ingin dicapai dan menggali pengetahuan prasyarat siswa dan apa yang akan dilaksanakan siswa dalam belajar kelompok. Kegiatan untuk memotivasi rasa ingin tahu siswa terhadap materi yang dipelajari. Siswa yang termotivasi akan siap untuk belajar dan akan mencapai hasil belajar yang lebih baik. Siswa yang siap untuk belajar lebih banyak dari pada siswa yang tidak siap. Sesuai pandangan (Masniladevi, 2003) bahwa siswa yang termotivasi tertarik dan mempunyai keinginan untuk belajar dan akan belajar lebih banyak.

\section{Kegiatan Belajar Kelompok}

Kegiatan bekerja dalam kelompok peneliti memberikan LKS kepada setiap anggota kelompok. Karena kelompok yang telah ditentukan sebelumnya maka dalam kegiatan ini siswa langsung menempati posisi sesuai kelompok masing-masing. Peneliti menjelaskan tugas siswa dan tugas kelompok, menjelaskan tanggung jawab setiap kelompok dan membagikan media yang dibutuhkan untuk menyelesaikan tugas kelompok. Media yang dibagikan berupa LKS, alat peraga berupa tanaman yang memiliki akar tunggang dan akar serabut. Pada siklus I siswa belum memiliki keberanian mengemukakan ide/pendapat pada saat diskusi kelas maupun diskusi kelompok dan siswa tidak antusias dalam menyelesaikan soal yang ada pada LKS karena peneliti kurang memberikan motivasi. Nanti pada tindakan siklus II siswa memiliki keberanian mengemukakan pendapat yang ada dalam pikirannya antusias dalam melakukan diskusi maupun menyelesaikan soal LKS Pembagian ini sesuai dengan pendapat (Masniladevi, 2003) bahwa siswa perlu diberi sumber-sumber belajar yang mendukung pelaksanaan model STAD. Tiap-tiap kelompok berusaha untuk memahami LKS. Setelah kelompok memahami perintah dalam LKS, mereka mulai bekerja dalam kelompok. Petunjuk yang ada dalam LKS merupakan bentuk bantuan bagi siswa, disamping itu pemanfaatan alat peraga juga dijelaskan dalam LKS. Siswa masih diberi kebebasan untuk mengungkapkan ide dan kreativitasnya bahwa pengetahuan dibentuk dan ditemukan oleh siswa secara aktif.
Siswa mengerjakan tugas kelompok secara berpasangan. Semua kelompok antusias bekerja memanipulasi benda konkret yaitu melakukan pengamatan terhadap dua macam tanaman yang berbeda. Penggunaan benda konkret dapat menciptakan pengalaman yang menyenangkan siswa dan juga dapat melibatkan siswa secara fisik dan mental dalam proses belajar sehingga dapat membangun pengetahuan mereka.

Pada kegiatan ini peneliti berfungsi sebagai mediator dan fasilitator. Peneliti memberi dorongan kepada siswa agar senantiasa bekerjasama, saling membantu mengatasi kesulitan, dan saling menghargai pendapat. Peneliti membantu siswa untuk bekerja secara kooperatif dan membimbing kelompok yang mengalami kesulitan. Peneliti juga bergabung dengan suatu kelompok untuk melihat dari dekat kegiatan dalam kelompok dan memberi bimbingan kalau diperlukan. Bahwa peneliti berperan sebagai mediator dan fasilitator untuk membantu siswa membangun pengetahuan.

Pemeriksaan Hasil Belajar Kelompok

Pemeriksaan hasil belajar kelompok dilakukan dengan memprentasekan hasil kegiatan kelompok di depan kelas oleh wakil setiap kelompok. Pada tahap ini terjadi interaksi antara kelompok penyaji dengan kelompok lain. Kegiatan ini dilakukan secara bergantian peneliti membagikan kunci jawaban setiap kelompok memperbaiki jawabannya jika masih terdapat kesalahan.

\section{Mengerjakan Soal Tes secara Individu}

Tes dilakukan secara klasikal dan dikerjakan secara individu. Disini masingmasing siswa berusaha dan bertanggungjawab secara individu untuk melakukan yang terbaik sebagai hasil belajar kelompok. Skor yang diperoleh siswa dari tes selanjutnya disumbangkan sebagai skor kelompok. Keberhasilan kelompok tergantung pada tanggungjawab masing-masing individu.

\section{Pemeriksaan Hasil Tes}

Pemeriksaan hasil tes dilakukan oleh peneliti membuat daftar skor peningkatan setiap individu, yang kemudian dimasukkan menjadi skor kelompok. Tujuannya untuk memberikan kepada siswa suatu sasaran yang dapat dicapai jika mereka bekeja dengan kesadaran memperlihatkan hasil yang lebih baik dibandingkan hasil yang telah dicapai sebelumnya. Skor peningkatan individual 
digunakan untuk memperoleh gambaran skor kelompok dengan cara mencatat skor peningkatan individual masing-masing anggota kelompok.

Peneliti mengingatkan siswa bahwa skor kelompok sangat tergantung dari sumbangan skor peningkatan masing-masing anggota kelompok. Keadaan ini dapat menyadarkan siswa berusaha untuk selalu meningkatkan kemampuanya setiap saat. Skor peningkatan individual dapat dilihat dan sekaligus ditentukan kelompok yang akan memperoleh skor terbaik dan berhak atas hadiah yang disediakan.

\section{Penghargaan Kelompok}

Kegiatan penghargaan kelompok dilakukan dengan memberikan hadiah sebagai penghargaan atas usaha yang telah dicapai kelompok selama belajar. Hadiah diberikan kepada kelompok yang dapat mencapai kriteria. Penghargaan kelompok didasarkan pada skorskor peningkatan yang diperoleh masingmasing anggota dan sangat mungkin tidak hanya satu kelompok yang mendapat penghargaan.

Berdasarkan hasil penelitian bahwa pada tindakan siklus I semua kelompok menunjukan tingkat pemerolehan hebat. Oleh karena itu, maka untuk memberikan penghargaan pada salah satu kelompok guru memutuskan satu kriteria baru yaitu melihat kembali hasil kerja LKS terbaik dari setiap kelompok. Dari kreteria tersebut di peroleh kelompok yang pantas memperoleh penghargaan yaitu kelompok II. Pada tindakan siklus II yang berhak mendapat penghargaan yaitu kelompok III dengan memperoleh poin 25 ke atas, kriteria yang di peroleh adalah super. Pada tindakan siklus III, ke 4 kelompok berhak mendapat penghargaan masing-masing kelompok memperoleh poin 25 ke atas dengan kriteria yang diperoleh adalah super.

Setiap anggota kelompok mempunyai kesempatan untuk mendapat penghargaan. Untuk skor rata-rata kelompok 25 ke atas maka penghargaan yang diperoleh kelompok adalah super, untuk skor rata-rata kelompok 25 ke bawah maka penghargaan yang diperoleh kelompok adalah hebat, dan skor rata-rata kelompok 15 maka penghargaan yang diperoleh kelompok adalah baik.

Penghargaan yang diberikan berupa hadiah yang tujuannya memotivasi siswa agar tetap aktif dalam belajar bahwa penghargaan diperlukan untuk meningkatkan sikap, rasa puas, dan rasa bangga siswa terhadap pembelajaran Matematika khususnya soal cerita operasi hitung campuran.

Sebagai akhir pembelajaran, masingmasing siswa diminta untuk menulis kesimpulan hasil pembelajaran berdasarkan hasil kerja kelompok. Kesimpulan ditulis agar pengetahuan siswa yang telah di dapat tertanam dalam otak siswa dan kesimpulan dapat dipelajari kembali waktu siswa lupa terhadap materi tersebut.

Pelaksanaan pembelajaran soal cerita operasi hitung campuran dengan menggunakan model STAD pembelajaran yang digunakan peneliti merupakan hal yang baru bagi mereka sehingga siswa merasa senang dalam mengikuti pembelajaran. Keterampilan kooperatif siswa dalam setiap siklus berkembang saat siswa bekerjasama dengan teman kelompoknya. Hal ini ditunjukan oleh kesediaan siswa secara terus menerus berada dalam kelompok, saling berbagi tugas kelompok, menunjukan sikap menghargai dan menghormati teman serta mengembangakan keterampilan bertanya. Memiliki kepedulian untuk memberikan dorongan kepada teman untuk memberi pendapat/ide.

Sesuai dengan hasil pengamatan, keterampilan yang sering muncul adalah berada dalam tugas, mengambil giliran dan berbagi tugas dan mendengarkan dengan aktif. Sementara keterampilan kooperatif lainya seperti mendorong partisipasi dan bertanya masih sedikit muncul, hal ini siswa belum terbiasa bekerja dalam kelompok kooperatif.

Kegiatan pembelajaran pada tindakan siklus I yang terdiri atas aktivitas siswa dan hasil evaluasi siswa pada materi soal cerita operasi hitung campuran belum mencapai hasil yang diharapkan, hal ini dilihat dari aktifitas siswa dalam mengikuti pembelajaran operasi hitung campuran baik dalam diskusi kelompok maupun diskusi kelas serta hasil evaluasi pemahaman siswa belum sesuai dengan kriteria keberhasilan yang telah ditetapkan yaitu 70. Penyebab belum tercapainya dikarenakan pengelolaan kelas belum berjalan secara optimal dan metode yang digunakan serta pengelolaan waktu.

Pada tindakan siklus I dalam pengelolaan pembelajaran kurang memberikan motivasi kepada siswa. Dilihat dari pelaksanaan pembelajaran baik dalam diskusi kelompok maupun diskusi kelas siswa tidak memiliki keberanian dalam mengemukakan pendapat/ide yang diperolehnya sehingga 
interaksi siswa dalam kelompok kelihatan tidak antusias. Serta dilihat dari pemahaman siswa menjawab soal tes secara tertulis masih mengalami kesulitan. Hal ini disebabkan kurang memahami kata kesimpulan. Akibatnya kemampuan siswa dalam menyerap dan memberikan pandangan/pendapat belum sampai pada tahap yang diinginkan. Kondisi pembelajaran pada tindakan siklus I berpengaruh pada hasil tes formatif siswa. Dari 16 siswa hanya 7 siswa yang mampu menjawab pertanyaan dengan baik. Ketuntasan belajar mecapai $43,75 \%$ sedangkan ketidaktuntasan $56,25 \%$. Sehingga perlu dilakukan upaya untuk meningkatkan pemahaman siswa pada siklus II dengan berpedoman pada rambu-rambu keberhasilan yang telah ditargetkan.

Pelaksanaan pembelajaran pada tindakan siklus II siswa dalam mengikuti langkah-langkah pembelajaran STAD dapat meningkat baik dalam diskusi kelompok maupun diskusi kelas serta pemahaman siswa menjawab soal tes secara tertulis. Peneliti dalam menjelaskan menekankan kepada siswa bahwa keberhasilan kelompok sangat berpengaruh pada kemampuan individu siswa. Oleh karena itu masing-masing siswa bertanggungjawab atas keberhasilan kelompoknya. Dan setiap mengajukan pertanyaan guru memberikan penguatan secara verbal maupun non verbal kepada siswa. Kondisi pembelajaran pada tindakan siklus II mengalami peningkatan dari 16 siswa 10 siswa yang mampu menjawab pertanyaan dengan baik. Ketuntasan belajar mecapai 62,5\% sedangkan ketidaktuntasan 37,5\%. Sehingga perlu dilakukan upaya untuk meningkatkan pemahaman siswa pada siklus III dengan berpedoman pada rambu-rambu keberhasilan yang telah ditargetkan.

Dalam hal ini peran guru sangat penting dalam kegiatan proses pembelajaran. Guru melakukan usaha-usaha untuk dapat menumbuhkan pemahaman siswa melalui interaksi sesama anggota kelompok untuk memudahkan dalam kegiatan belajar. Adanya pemahaman yang baik dalam belajar akan menunjukan hasil yang lebih baik. Sesuai dengan pendapat (Sardiman, 2007: 86) dengan adanya usaha yang tekun dan terutama didasari adanya motivasi, maka seseorang yang belajar itu akan memberikan pengetahuan dan pemahaman yang lebih banyak dan dapat melahirkan prestasi yang baik.
Indikator keberhasilan yang di tetapkan oleh peneliti belum tercapai, sehingga untuk lebih memaksimalkan kemampuan siswa dalam menyelesaikan soal cerita operasi hitung campuran dengan menggunakan model kooperatif tipe STAD maka peneliti akan melanjutkan ke siklus III. pada pembelajaran siklus III sudah dikatakan berhasil dari pelaksanaan dua siklus sebelumnya. Keberhasilan ini ditandai dengan tercapainya seluruh indikator yang telah ditetapkan dalam lembar observasi guru dan siswa. Keberhasilan juga dapat di lihat dengan nilai pencapaian prestasi belajar siswa berkisar 16 orang (semua siswa) telah memperoleh nilai rata-rata 70 dengan ketuntasan belaar $100 \%$. Hal ini sudah mencapai target yakni setiap siswa telah memperoleh nilai minimal 70 dengan ketuntasan belajar $70 \%$.

\section{KESIMPULAN \& SARAN}

Berdasarkan uraian yang telah dipaparkan maka dapat disimpulkan metode pembelajaran mind mapping efektif dilakukan dalam meningkatkan kemampuan menyimak dongen di sekolah dasar kelas I SD Inpres Panrenge Kabupaten Barru. Berdasarkan rumusan masalah, paparan data dan pembahasan hasil penelitian maka dapat disimpulkan bahwa :1) Penerapan model kooperatif tipe student achievement division (STAD) dalam pembelajaran soal cerita operasi hitung campuran di kelas III SDN 44 Parepare sudah terlaksana sesuai dengan langkah-langkah kooperatif tipe STAD. 2) Hasil belajar siswa pada soal cerita operasi hitung campuran di kelas III SDN 44 Parepare mengalami peningkatan melalui penerapan model kooperatif tipe studen tiem arcievement division (STAD) dan mencapai ketuntasan yang ditetapkan.

\section{DAFTAR PUSTAKA}

Asdar. 2002. Pembelajaran Dalam Upaya Membantu Mengatasi Kesulitan Siswa Menyelesaikan Soal Perkalian Bentuk Cerita di Kelas III SDN Sumbersari IV Kota Malang. Tesis. Malang: Unifersitas Negeri Malang program pasca sarjana jurusan pendidikan matematika SD.

Hamdani. 2009. Soal cerita matematika (online) (http:///arsip pontianak post.com/ $\mathrm{html}$, diakses 20 april 2009)

Depdiknas.2006. Kurikulum Tingkat Satuan Pendidikan(KTSP). Jakarta : Depdiknas 
Masniladevi. 2003. Keefektifan Belajar Kooperatif Model STAD (students teams- achienvement divisioan) pada Penjumlahan Pecahan di Kelas IV SD Negeri Sumbersari III Kota Malang. Tesis. Malang: Universitas Negeri Malang.

Nur Asma. 2006. Model Pembelajaran Kooperatif. Jakarta: Departemen Pendidikan Nasional

Slavin E. Robert. 2008. Cooperatif Learning. Bandung:Nusa media Sugiarto,joko,dkk.2007.Terampil berhitung matematika III.Jakarta:Erlangga

Sudarmadi, dkk.1998 . Bahan Pembinaan Matematika Sekolah Dasar. Jakarta: Depdikbud

Sudarsono, F.X. 1996. Pedoman Pelaksanaan Penelitian Tindakan Kelas: Rencana Desain dan Implementasinya. Yokyakarta: UP3SD

Trisni. 2007. STAD dalam Matematika, (online), (http:///blogspot.com/ html, diakses 5 Mei 2009)

Wardani, I.G.A.K. 2005. Penelitian Tindakan Kelas. Jakarta: PT Bumi Aksara.

Wena. 2008. Strategi Pembelajaran Inovatif Kontemporer. Malang: Bumi Aksara. 